\title{
PENINGKATAN KEMAMPUAN GURU DALAM PENGELOLAAN KELAS MELALUI ACTIVE KNOWLEDGE SHARING SD NEGERI 1 WONOKARTO TAHUN PELAJARAN 2019/2020
}

\author{
Dra. Diyassi \\ SD Negeri 1 Wonokarto Kecamatan Wonogiri Kabupaten Wonogiri \\ diyassiaja@gmail.com
}

\begin{abstract}
Abstrak
Penelitian ini bertujuan untuk meningkatkan kemampuan guru SD Negeri 1 Wonokarto Tahun Pelajaran 2019/2020 dalam pengelolaan kelas melalui penerapan active knowledge sharing. Penelitian menggunakan rancangan Penelitian Tindakan Sekolah (PTS) yang dilaksanakan dalam 2 (dua) siklus, dilaksanakan di SD Negeri 1 Wonokarto dengan subjek penelitian semua guru SD Negeri 1 Wonokarto Tahun Pelajaran 2019/2020 yang berjumlah 8 orang guru. Metode penelitian menggunakan Penelitian Tindakan Sekolah. Penilaian Kemampuan Guru dilakukan dengan teknik observasi dengan lembar observasi. Validasi data dilakukan dengan teknik triangulasi. Pengumpulan data dilakukan melalui observasi. Analisis data dilakukan dengan teknik analisis deskriptip komparatif. Data empirik hasil penelitian menunjukkan bahwa melalui Active Knowledge Sharing dapat meningkatkan kemampuan guru SD Negeri 1 Wonokarto Tahun Pelajaran 2019/2020 dalam pengelolaan kelas. Dari kondisi awal nilai rata-rata kemampuan guru hanya 43,1 atau D kualifikasi Kurang, meningkat pada siklus I nilai rata-rata kemampuan guru menjadi 69,8 atau C kualifikasi Cukup, dan meningkat lagi pada siklus II nilai rata-rata kemampuan guru menjadi 78,5 atau B kualifikasi Baik. Peningkatan juga ditunjukkan dari kondisi awal pada indikator komponen dengan 3 indikator komponen Kurang dan 7 indikator komponen Sangat Kurang dengan rata-rata E atau kualifikasi Sangat Kurang, meningkat pada siklus I dengan indikator komponen 2 indikator komponen Baik, 4 indikator komponen Cukup dan 4 indikator komponen Kurang dengan rata-rata $\mathrm{C}$ atau kualifikasi Cukup. Meningkat lagi pada siklus II menjadi ada 4 indikator komponen Amat Baik, dan 6 indikator komponen Baik, dengan rata-rata komponen B atau Baik. Kesimpulan dari data di atas adalah melalui penerapan active knowledge sharing dapat meningkatkan kemampuan guru SD Negeri 1 Wonokarto dalam pengelolaan kelas Tahun Pelajaran 2019/2020
\end{abstract}

Kata kunci : Kemampuan Guru, Pengelolaan Kelas, Active Knowledge Sharing

\begin{abstract}
This study aims to improve the ability of teachers in Wonokarto Public Elementary School 2019/2020 Academic Year in classroom management through the application of active knowledge sharing. The study used a School Action Research (PTS) design which was carried out in 2 (two) cycles, carried out in SD Negeri 1 Wonokarto with the research subjects being all SD Negeri 1 Wonokarto teachers in 2019/2020 Academic Year totaling
\end{abstract}


8 teachers. The research method uses School Action Research. Teacher Ability Assessment is done by observation technique with an observation sheet. Data validation is done by triangulation techniques. Data collection is done through observation. Data analysis was performed using comparative descriptive analysis techniques. Empirical data on the results of the study indicate that through Active Knowledge Sharing can improve the ability of teachers in SD Negeri 1 Wonokarto 2019/2020 Academic Year in classroom management. From the initial conditions the average value of the teacher's ability is only 43.1 or D qualification Less, increased in the first cycle the average value of the ability of the teacher to be 69.8 or $\mathrm{C}$ sufficient qualifications, and increased again in the second cycle the average value of the ability of teachers to be 78.5 or B Good qualifications. Improvements were also shown from initial conditions on component indicators with 3 component indicators Poor and 7 component indicators Very Poor with average E or Very Poor qualifications, increased in cycle I with component indicators 2 Good component indicators, 4 Sufficient component indicators and 4 component indicators Not enough with an average $\mathrm{C}$ or enough qualifications. Increasing again in cycle II there are 4 indicators of Very Good components, and 6 indicators of Good components, with an average component of $\mathrm{B}$ or Good. The conclusion from the above data is through the application of active knowledge sharing can improve the ability of teachers of SD Negeri 1 Wonokarto in class management 2019/2020 Academic Year

Keywords: Teacher's Ability, Classroom Management, Active Knowledge Sharing

\section{PENDAHULUAN}

Kondisi belajar yang optimal dapat dicapai jika guru mampu mengatur siswa dan sarana pengajaran serta mengendalikannya dalam suasana yang menyenangkan untuk mencapai tujuan pelajaran. Selain itu, penciptaan kelas yang kondusif juga menjadi salah satu peranan penting bagi seorang guru. Di dalam kelas proses pembelajaran dilakukan, guru menggunakan metode dengan pendekatannya, menyampaikan materi dengan sumber belajar yang bertemu dan berinteraksi di dalam kelas. (Rina dan Benedictus, 2016: 37).

Pengelolaan kelas dalam pengelolaan pembelajaran atau pengajaran adalah dua kegiatan yang sangat erat hubungannya namun dapat dan harus dibedakan satu sama lain karena tujuannya berbeda. Pengajaran mencakup kegiatan yang secara langsung dimaksudkan untuk mencapai tujuan-tujuan khusus pengajaran yaitu pembiasaan peserta didik, menyusun rencana pelajaran, memberi informasi, bertanya, menilai, dan sebagainya, maka pengelolaan kelas menunjuk kepada kegiatan-kegiatan yang menciptakan dan mempertahankan kondisi yang optimal bagi terjadinya proses belajar. Sehingga dalam proses belajar mengajar di sekolah dapat dibedakan adanya dua kelompok masalah yaitu masalah pengajaran dan masalah pengelolaan kelas. 
Pengelolaan kelas merupakan tantangan penting yang dihadapi guru. Seorang guru akan dikenal baik oleh siswa, guru lain, sekolah, dan orang tua siswa bila kemampuan mengelola kelasnya juga baik, yaitu: dapat menangani pembelajaran, menciptakan lingkungan belajar yang tertib, dan menangani berbagai permasalahan dan perilaku siswa. Selain itu, penggunaan media pembelajaran digunakan untuk mempermudah penyampaian materi pembelajaran. Dengan pengelolaan kelas yang baik dalam pembelajaraan maka proses pembelajaran akan berlangsung secara efektif dan efesien sehingga hasil belajar yang akan diinginkan akan tercapai. (Siwi, 2018).

Namun pada kenyataannya masih jauh dari harapan. Hasil pengamatan dari kepala sekolah yang sekaligus peneliti di SD Negeri 1 Wonokarto tahun pelajaran 2019/2020 menunjukkan bahwa kemampuan guru masih rendah dalam pengelolaan kelas.

Berdasarkan data hasil observasi awal penulis sebagai kepala SD Negeri 1 Wonokarto menunjukkan bahwa guru tida ada yang masuk predikat Baik atau Amat Baik, hasilnya hanya 2 orang guru (25\%) yang masuk predikat Cukup, 2 orang guru $(25 \%)$ yang masuk predikat Kurang dan masih ada 4 orang guru (50 $\%)$ yang masuk predikat Sangat Kurang. Rata-rata bernilai 43,1 atau D kualifikasi Kurang.

Pada indikator komponen pengelolaan kelas ada 3 butir komponen Kurang dan 7 indikator komponen Sangat Kurang, dengan rata-rata capaian indikator komponen Sangat Kurang atau E.

Mengetahui permasalahan rendahnya kemampuan guru dalam pengelolaan kelas, penulis berencana untuk melaksanakan suatu penelitian tindakan melalui pelaksanaan active knowledge sharing. Strategi Active knowledge sharing (Berbagi Pengetahuan dan Diskusi) adalah sebuah teknik yang sesuai untuk menarik para peserta dengan segera kepada materi pelajaran dengan cara saling berbagi/bertukar pengetahuan.

Berdasarkan latar belakang masalah di atas maka dapat dirumuskan permasalahan yang ada dalam penelitian ini, yaitu "Apakah melalui pelaksanaan active knowledge sharing dapat meningkatkan kemampuan guru dalam 
pengelolaan kelas di SD Negeri 1 Wonokarto Kecamatan Wonogiri Kabupaten Wonogiri Semester I tahun pelajaran 2019/2020?"

Manfaat yang ingin dicapai dalam penelitian ini antara lain: 1. Bagi peneliti: a. Sebagai sarana pengembangan pengetahuan bagi para guru dalam program peningkatan kualitas pembelajaran di sekolah; b. Sebagai upaya peningkatan kualitas pendidikan, khususnya kemampuan guru dalam pengelolaan kelas; 2.Bagi guru: a. Melalui penerapan active knowledge sharing dapat memberikan pengalaman belajar bagi guru; b. Guru dapat memiliki kemampuan dalam mendesain model-model dan media pembelajaran sebagai dijadikan alternatif guru dalam pembelajaran; 3. Bagi kepala sekolah sejenis: a. Sebagai konstribusi pemikiran mengenai kinerja guru dalam pengelolaan kelas; b. Sebagai input bagi untuk peningkatan kualitas pembelajaran pada jenjang pendidikan sekolah dasar; c. Sebagai bahan pertimbangan dalam melakukan supervisi atau mengkaji optimalisasi kemampuan guru dalam pengelolaan kelas.

\section{a. Hakikat Kemampuan Guru}

Kemampuan guru berasal dari kata kemampuan dan guru. Kemampuan dalam Kamus Bahasa Indonesia terbitan Pusat Bahasa Departemen Pendidikan Nasional tahun 2010, dari kata mampu yang berati: kuasa (bisa, sanggup) melakukan sesuatu; dapat. Sedangkan kemampuan adalah kesanggupan; kecakapan; kekuatan (Dendy Sugono, 2010: 979). Guru berarti orang yg pekerjaannya (mata pencahariannya,profesinya) mengajar. (Dendy Sugono, 2010: 509). Jadi kemampuan guru adalah kesanggupan profesi mengajar.

Kemampuan merupakan perpaduan dari pengetahuan, keterampilan, nilai dan sikap yang direfleksikan dalam kebiasaan berpikir dan bertindak. Pada sistem pengajaran, kemampuan digunakan untuk mendeskripsikan kemampuan profesional yaitu kemampuan untuk menunjukkan pengetahuan dan konseptualisasi pada tingkat yang lebih tinggi. Kompetensi ini dapat diperoleh melalui pendidikan, pelatihan dan pengalaman lain sesuai tingkat kompetensinya. (Mantja, 2007: 38). 
Kemampuan guru merupakan karakteristik yang menonjol bagi seseorang dan menjadi cara-cara berperilaku dan berfikir dalam segala situasi, dan berlangsung dalam periode waktu yang lama.

Berkenaan dengan standar kemampuan guru, Wijaya, dan Tabrani (2012: 49) bahwa, standar kemampuan guru itu berhubungan dengan kualitas guru dalam menjalankan tugasnya seperti: 1) bekerja dengan siswa secara individual; 2) persiapan dan perencanaan pembelajaran; 3) pendayagunaan media pembelajaran; 3) melibatkan siswa dalam berbagai pengalaman belajar; 4) kepemimpinan yang aktif dari guru.

Kemampuan guru mempunyai spesifikasi tertentu. Kemampuan guru dapat dilihat dan diukur berdasarkan spesifikasi/kriteria kompetensi yang harus dimiliki oleh setiap guru. Berkaitan dengan kemampuan guru, wujud perilaku yang dimaksud adalah kegiatan guru dalam proses pembelajaran yaitu bagaimana seorang guru merencanakan pembelajaran, melaksanakan kegiatan pembelajaran, dan menilai hasil belajar.

\section{b. Pengelolaan Kelas}

Menurut Iskandar (2009: 210-211) pengelolaan kelas merupakan kegiatan yang terencana dan sengaja dilakukan oleh guru dengan tujuan menciptakan dan mempertahankan kondisi yang optimal, sehingga proses pembelajaran dapat berjalan secara efektif dan efisien”.

Sedangkan Ade Rukmana \& Asep Suryana, (2006: 29) menjelaskan bahwa pengelolaan kelas adalah segala usaha yang diarahkan untuk mewujudkan suasana pembelajaran yang efektif dan menyenangkan serta dapat memotivasi siswa untuk belajar dengan baik sesuai dengan kemampuan.

Menurut Uzer (2005: 10) pengelolaan kelas mempunyai tujuan yaitu untuk: 1) menyediakan dan menggunakan fasilitas belajar untuk bermacammacam kegiatan pembelajaran agar mencapai hasil yang baik; 2) mengembangkan kemampuan siswa dengan menggunakan alat-alat belajar; 3) menyediakan kondisi-kondisi yang memungkinkan siswa belajar; 4) membantu siswa untuk memperoleh hasil yang diharapkan. 
Guna memperkecil masalah gangguan dalam kelas, prinsip-prinsip pengelolaan kelas dapat dipergunakan. Maka sangat penting bagi guru untuk mengetahui dan menguasai prinsip-prinsip pengeloalan kelas. Adhayati (2016: 38), menyebutkan prinsip-prinsip keterampilan mengelola kelas yaitu: 1) kehangatan dan keantusiasan dalam mengajar, yang dapat menciptakan iklim kelas yang menyenangkan; 2) menggunakan kata-kata atau tindakan yang dapat menantang siswa untuk berpikir; 3) menggunakan berbagai variasi yang dapat menghilangkan kebosanan; 4) keluwesan guru dalam pelaksanaan tugas; 5) penekanan pada hal-hal yang bersifat positif; 6) penanaman disiplin diri sendiri.

Dari definisi pengelolaan kelas yang dipaparkan di atas, dapat disimpulkan bahwa pengelolaan kelas lebih menitik beratkan kepada penciptaan suasana belajar yang efektif. Hal ini dikarenakan belajar tanpa suasana yang efektif dan mendorong siswa untuk belajar, akan menjadikan siswa merasa terpaksa untuk belajar di dalam kelas.

\section{c. Active Knowledge Sharing}

Menurut Zaini (2008: 22) active knowledge sharing (berbagi pengetahuan aktif) adalah salah satu strategi yang dapat membawa siswa untuk siap belajar materi pelajaran dengan cepat serta dapat digunakan untuk melihat tingkat kemampuan siswa untuk membentuk kerja sama tim.

Menurut Silberman (2009: 100) mengatakan bahwa stategi ini merupakan cara yang bagus untuk mengenalkan siswa kepada materi pelajaran yang guru ajarkan. Guru juga dapat menggunakannya untuk menilai tingkat pengetahuan siswa sembari melakukan kegiatan pembentukan tim.

Active Knoeledge Sharing merupakan strategi yang menekankan siswa untuk saling berbagi dan membantu dalam menyelesaikan pertanyaan yang diberikan. Atau dengan kata lain, “ ketika ada siswa yang tidak mampu menjawab pertanyaan atau kesulitan menjawab, maka siswa lain yang mampu menjawab pertanyaan dapat membantu temannya untuk menyelesaikan pertanyaan yang diberikan" (Dewi, 2012: 8). 
Active knowledge sharing dapat membentuk siswa dalam kerja sama tim dalam diskusi (bertukar pengetahuan) dan dapat membuat siswa siap materi terlebih dahulu karena sebelum materi di ajarkan siswa diberikan pertanyaan terlebih dulu yang berkaitan dengan materi. Active knowledge sharing dapat melibatkan siswa secara aktif, dimana mereka dalam kelompoknya dapat berdiskusi (Nafi'a, 2012: 8).

Jadi active knowledge sharing merupakan strategi belajar aktif yang mendorong siswa aktif berbagi informasi dan pengetahuan kepada teman yang tidak bisa menyelesaikan soalnya dan sesi akhirnya guru menyampaikan topiktopik yang penting dari hasil pengerjaan siswa dalam berbagi pengetahuan pada mata pelajaran tersebut.

Strategi active knowledge sharing merupakan salah satu strategi yang dapat membawa peserta didik untuk siap belajar materi pelajaran dengan cepat serta dapat digunakan untuk dapat melihat tingkat kemampuan peserta didik dalam membentuk kerja sama tim. Strategi ini menuntut siswa untuk mampu bekerja sama untuk memecahkan suatu permasalahan. Strategi ini juga dapat digunakan pada hampir semua materi pelajaran. Langkah-langkah yang dilakukan dalam strategi active knowledge sharing yaitu: 1) Membuat pertanyaanpertanyaan yang berkaitan dengan materi pelajaran yang akan diajarkan. Dimana pertanyaan-pertanyaan tersebut dapat berupa definisi atau istilah, pertanyaan, mengidentifikasi, menanyakan sikap atau tindakan yang mungkin dilakukan; 2) Minta peserta didik untuk menjawab dengan sebaik-baiknya; 3) Gunakan jawaban-jawaban yang muncul sebagai jembatan untuk mengenalkan topik yang penting (Silberman, 2009: 101).

Fakta yang terjadi pada guru SD Negeri 1 WonokartoTahun Pelajaran 2019/2020 adalah kemampuan sebagian besar guru masih rendah dalam pengelolaan kelas. Untuk mengatasi permasalahan rendahnya kemampuan guru dalam pengelolaan kelas maka peneliti sebagai kepala sekolah merancang Penelitian Tindakan Sekolah melalui penerapan active knowledge sharing. Tujuan active knowledge sharing adalah agar guru dapat mengembangkan potensi dirinya secara optimal dan mendapat kemajuan dalam bekerja. 


\section{METODE PENELITIAN}

Tempat penelitian adalah di SD Negeri 1 Wonokarto Kecamatan Wonogiri, Kabupaten Wonogiri. Alasan pemilihan lokasi penelitian ini adalah: 1) Kepala sekolah sebagai peneliti melihat adanya indikasi rendahnya kemampuan guru dalam pengelolaan kelas; 2) Materi penelitian ini tidak menyimpang dari tugas pokok kepala sekolah dasar, yaitu menilai kinerja guru, yang salah satunya menilai guru dalam mengelola kelas; 3) Pengelolaan kelas yang wajib dilakukan oleh guru akan mudah diteliti tingkat keberhasilannya, karena pengelolaan kelas oleh guru dapat diamati dari dekat.

Penelitian Tindakan Sekolah ini dilaksanakan Tahun Pelajaran 2019/2020 selama empat bulan. Penelitian dimulai pada bulan Agustus 2019 sampai bulan November 2019. Pelaksanaan penelitian meliputi: tahap pencarian ijin dan penyusunan instrumen, dilanjutkan dengan pelaksanaan tindakan siklus I dan siklus II. Berikutnya tahap analisis data dan terakhir penyusunan laporan hasil penelitian.

Subjek Penelitian Tindakan Sekolah ini adalah guru SD Negeri 1 Wonokarto Tahun Pelajaran 2019/2020 yang berjumlah 8 orang. Terdiri dari yang 6 kelas, 1 guru mata pelajaran Agama Islam, 1 guru mata pelajaran PJOK. Objek Penelitian Tindakan Sekolah ini adalah peningkatan kemampuan guru SD Negeri 1 Wonokarto Tahun Pelajaran 2019/2020 dalam pengelolaan kelas melalui penerapan active knowledge sharing.

Sumber data yang digunakan dalam penelitian ini adalah: Data kondisi awal yang berupa hasil penilaian kemampuan guru SD Negeri 1 Wonokarto dalam pengelolaan kelas pada kondisi awal. Data siklus I yang berupa hasil penilaian kemampuan guru SD Negeri 1 Wonokarto dalam pengelolaan kelas pada siklus I. Data Siklus II yang berupa hasil penilaian kemampuan guru SD Negeri 1 Wonokarto dalam pengelolaan kelas pada siklus II.

Data penilaian hasil penilaian kemampuan guru SD Negeri 1 Wonokarto dalam pengelolaan kelas pada kondisi awal, sebelum pelaksanaan PTS dikumpulkan dengan teknik observasi. Instrumen yang digunakan adalah lembar penilaian kemampuan guru dalam pengelolaan kelas pada kondisi awal. Data 
penilaian hasil penilaian kemampuan guru SD Negeri 1 Wonokarto dalam pengelolaan kelas pada siklus I dikumpulkan dengan teknik observasi. Instrumen yang digunakan adalah lembar penilaian kemampuan guru dalam pengelolaan kelas siklus I. Data penilaian hasil penilaian kemampuan guru SD Negeri 1 Wonokarto dalam pengelolaan kelas pada siklus II dikumpulkan dengan teknik observasi. Instrumen yang digunakan adalah lembar penilaian kemampuan guru dalam pengelolaan kelas siklus II.

Validasi data hasil penilaian kemampuan guru SD Negeri 1 Wonokarto dalam pengelolaan kelas pada kondisi awal, siklus I dan siklus II, peneliti menggunakan triangulasi data. Yaitu dengan cara membandingkan hasil penilaian peneliti dengan hasil penilaian kolaborator, kemudian dikonfirmasikan kepada guru yang dinilai.

Teknik analisis data dengan deskriptif komparatif. Prakteknya yaitu membandingkan data hasil penilaian kemampuan guru pada siklus I dengan kondisi awal, dan membandingkan hasil penilaian kemampuan guru pada siklus II dengan hasil penilaian pada siklus I. Hal ini dilakukan untuk mengetahui peningkatan kemampuan guru SD Negeri 1 Wonokarto dalam pengelolaan kelas pada kondisi awal, siklus I dan siklus II.

Analisis data dalam penelitian ini juga menggunakan analisis data kualitatif yaitu analisis berdasarkan penalaran logika. Analisis tersebut digunakan atas pertimbangan bahwa, jenis data yang diperoleh berbentuk aktivitas guru dalam mengikuti kegiatan pembinaan melalui active sharing knowledge.

Indikator kerja penelitian secara umum dapat dilihat dari adanya peningkatan kemampuan guru SD Negeri 1 Wonokarto dalam pengelolaan kelas dari kondisi awal ke siklus I dan siklus II. Keberhasilan tindakan pada siklus I diketahui dengan cara membandingkan hasil penilaan kemampuan guru siklus I dengan kondisi awal. Sedangkan keberhasilan tindakan pada siklus II dengan cara membandingkan hasil penilaan kemampuan guru siklus I dengan siklus I. Sedangkan indikator kerja tindakan dapat dilihat dari kriteria yang telah ditentukan peneliti, sebagai berikut: 1) Adanya peningkatan kemampuan guru SD Negeri 1 Wonokarto dalam pengelolaan kelas dari kondisi awal ke siklus I, dan 
dari siklus I ke siklus II; 2) Nilai rata-rata kemampuan guru SD Negeri 1 Wonokarto dalam pengelolaan kelas mencapai kualifikasi Baik; 3) Semua guru SD Negeri 1 Wonokarto kemampuan pengelolaan kelasnya minimal masuk kualifikasi Baik.

Penelitian ini menggunakan rancangan Penelitian Tindakan Sekolah. Penelitian ini dilaksanakan dalam dua siklus, masing-masing siklus melalui tahap perencanaan tindakan, pelaksanaan tindakan, observasi dan refleksi.

Hipotesis dalam penelitian ini adalah, "Diduga melalui pelaksanaan active knowledge sharing dapat meningkatkan kemampuan guru dalam pengelolaan kelas di SD Negeri 1 Wonokarto Kecamatan Wonogiri Kabupaten Wonogiri Semester I Tahun Pelajaran 2019/2020.”

\section{HASIL PENELITIAN DAN PEMBAHASAN}

\section{a. HASIL PENELITIAN}

\section{Deskripsi Kondisi Awal}

Berdasarkan data hasil observasi awal penulis sebagai kepala SD Negeri 1 Wonokarto menunjukkan bahwa guru tida ada yang masuk predikat Baik atau Amat Baik, hasilnya hanya 2 orang guru (25\%) yang masuk predikat Cukup, 2 orang guru $(25 \%)$ yang masuk predikat Kurang dan masih ada 4 orang guru (50 \%) yang masuk predikat Sangat Kurang. Rata-rata bernilai 43,1 atau D kualifikasi Kurang.

Pada indikator komponen pengelolaan kelas yang mencapai nilai D atau klasifikasi Kurang ada 3 sedangkan yang 7 butir masing Sangat Kurang atau E.

\section{Deskripsi Siklus I}

Perencanaan siklus I meliputi: 1) Permohonan ijin penelitian pada minggu pertama bulan Agustus 2019, pada hari Kamis, tanggal 1 Agustus 2019; 2) Penyusunan rencana Penelitian Tindakan Sekolah dengan kegiatan Active Knowledge Sharing.dilakukan pada minggu kedua bulan Agustus 2019, pada hari Rabu, tanggal 7 Agustus 2019; 3) Membuat instrumen penelitian yang meliputi: daftar hadir guru dan lembar penilaian kemampuan guru dalam pengelolaan kelas, 
dilaksanakan pada tanggal 15 Agustus 2019 dan 22 Agustus 2019; 4) Menyusun jadwal pelaksanaan Active Knowledge Sharing pada tanggal 29 Agustus 2019.

Tindakan siklus I terdiri dari 3 kegiatan utama dengan rincian sebagai berikut: 1) Pertemuan 1 (Sabtu, 7 September 2019) dan Pertemuan 2 (Sabtu, 14 September 2019) dengan Kegiatan Awal, Kegiatan Inti, Kegiatan Akhir. Pertemuan 3 (Kamis, Jumat dan Sabtu, tanggal 19, 20 dan 21 September 2019) pada pertemuan 3 ini dilakukan penilaian kemampuan guru dalam pengelolaan kelas dengan observasi langsung ketika proses pembelajaran di kelas. Pada hari Kamis, 19 September 2019 yang dinilai guru kelas 1, 2, 3, 4, dan Jumat, 20 September 2019 yang dinilai guru kelas 5, 6, serta hari Sabtu, 21 September 2019 yang dinilai guru PJOK dan Guru Pendidikan Agama.

Observasi bersamaan dengan pertemuan ketiga siklus I. Pada siklus I peneliti sudah melaksanakan tindakan penelitian melalui pelaksanaan Active Knowledge Sharing secara kelompok. Kemampuan guru dalam pengelolaan kelas dari hasil observasi siklus I bahwa guru yang hasilnya Baik ada 3 orang guru dengan nilai 70; 72,5; 75; setara dengan 37,5 \%; yang masuk predikat Cukup, ada 5 orang guru dengan nilai dari 62, 5 sampai dengan 67,5; setara dengan 62,5 \%. Rata-rata nilai 69,8 kategori $\mathrm{C}$ atau kualifikasi Cukup. Rata-rata nilai 69,8 kategori C kualifikasi Cukup.

Pada data di atas, komponen pengelolaan kelas yang mencapai nilai B atau klasifikasi Baik ada 2 indikator, sedangkan yang mencapai nilai $\mathrm{C}$ atau klasifikasi Cukup ada 4 indikator, dan 4 indikator masing Kurang atau D.

Sedangkan catatan temuan untuk mengembangan kegiatan Active Knowledge Sharing adalah sebagai berikut: 1) Interaksi antara kelompok satu dengan yang lain belum bisa berjalan; 2) Kelompok peserta active knowledge sharing kurang mendapatkan peluang untuk menafsirkan/mendiskusikan pengamatan dari hasil sharing; 3) Kegiatan diskusi dengan penyampai materi sebagai moderator belum bisa berjalan dengan baik; 4) Hasil yang diharapkan mencapai B atau Baik baru mencapai rata-rata $\mathrm{C}$ atau Cukup.

Kemampuan guru SD Negeri 1 Wonokarto dalam pengelolaan kelas pada siklus I jika dibandingkan dengan kondisi awal menunjukkan peningkatan, yaitu 
rata-rata kemampuan guru sudah masuk kualifikasi Cukup dan jumlah guru yang masuk kualifikasi Baik meningkat, dari sebelumnya tidak ada. Namun peningkatannya belum memenuhi indikator kinerja penelitian ini, karena baru 3 orang, dan komponen indikator baru dicapai 2 yang Baik.

Refleksi, setelah dilaksanakan tindakan penelitian siklus I melalui penerapan Active Knowledge Sharing, kemampuan guru SD Negeri 1 Wonokarto dalam pengelolaan kelas menunjukkan peningkatan.

Pada siklus I peneliti sudah melaksanakan tindakan penelitian melalui pelaksanaan Active Knowledge Sharing secara kelompok. Kemampuan guru dalam pengelolaan kelas termasuk dalam kualifikasi Cukup dengan rata-rata nilai 69,8 . Ada 3 orang guru $(37,5 \%)$ yang masuk kualifikasi Baik, ada 5 orang guru $(62,5,0 \%)$ masuk kualifikasi Cukup. Nilai rata-rata kemampuan guru dalam pengelolaan kelas pada siklus I adalah 69,8 masuk kualifikasi Cukup.

Komponen kemampuan pengelolaan kelas guru SD Negeri 1 Wonokarto yang tercapai pada siklus I jika dibandingkan dengan kondisi awal meningkat. Pada kondisi awal ada 3 indikator komponen beroleh Kurang dan 7 indikator beroleh Sangat Kurang. Rata-rata E kualifikasi Sangat Kurang.

Pada siklus I ada 2 indikator komponen beroleh Baik, 4 indikator beroleh Cukup, 4 indikator Kurang Sedangkan peningkatan, yaitu rata-rata kemampuan guru sudah masuk kualifikasi Cukup dan jumlah guru yang masuk kualifikasi Baik ada 2 orang. Rata-rata C kualifikasi Cukup.

Hal di atas menunjukkan meningkat, karena dari tidak ada kualifikasi Baik pada kondisi awal, sudah mendapatkan Baik pada siklus I. Namun peningkatannya belum memenuhi indikator kinerja penelitian ini, karena masih ada guru yang kemampuan pengelolaan kelasnya masih masuk kualifikasi Cukup. Karena peningkatan kemampuan guru yang dicapai pada siklus I masih belum memenuhi indikator kinerja dalam penelitian ini, maka peneliti memutuskan untuk melanjutkan Penelitian Tindakan Sekolah ke siklus II dengan tetap menerapkan Active Knowledge Sharing secara kelompok dengan bimbingan intensif

\section{Deskripsi Siklus II}


Perencanaan pada siklus II didasarkan pada perbaikan dari kekurangan yang terjadi pada siklus II. Perbaikan yang dilaksanakan guru peserta dalam mengelola kelas atas saran dari peneliti antara lain: 1) Kerja kelompok dilaksanakan dengan posisi duduk dalam kelompok kecil melingkar; 2) Peneliti memberikan bimbingan intensif kepada guru yang mengalami kesulitan dalam pengelolaan kelas.

Pada kegiatan perencanaan peneliti : 1) Menyusun rencana kegiatan Penelitian Tindakan Sekolah dengan pelaksanaan Active Knowledge Sharing secara kelompok dengan bimbingan intensif; 2) Membuat instrumen peneitian yang meliputi: daftar hadir guru dan lembar penilaian kemampuan guru dalam pengelolaan kelas; 3) Menyusun jadwal pelaksanaan Active Knowledge Sharing.

Tindakan siklus II terdiri dari Pertemuan 1 (Sabtu, 28 September 2019) dan Pertemuan 2 (Sabtu, 5 Oktober 2019) Pertemuan 3 (Kamis, Jumat dan Sabtu, tanggal 10, 11, dan 12 Oktober 2019) Penilaian kemampuan guru dalam pengelolaan kelas dengan observasi langsung ketika proses pembelajaran di kelas. Pada hari Kamis, 10 Oktober 2019 yang dinilai guru kelas 1, 2, 3, 4, dan Jumat, 11 Oktober 2019 yang dinilai guru kelas 5, 6, serta hari Sabtu, 12 Oktober 2019 yang dinilai guru PJOK dan Guru Pendidikan Agama.

Observasi pada siklus II peneliti sudah melaksanakan tindakan penelitian melalui pelaksanaan Active Knowledge Sharing secara efektif. Kemampuan guru dalam pengelolaan kelas dari hasil observasi siklus II bahwa guru yang hasilnya Amat Baik ada 2 orang guru dengan nilai 87,5 setara dengan $25 \%$ guru; yang masuk predikat Baik ada 6 orang guru dengan nilai dari 72, 5 sampai dengan 80 setara dengan $75 \%$ orang guru. Rata-rata nilai 78,5 kategori B kualifikasi Baik

Pada data di atas, komponen pengelolaan kelas yang mencapai nilai A atau klasifikasi Amat Baik ada 5 indikator, sedangkan yang mencapai nilai B atau klasifikasi Baik ada 4 indikator, dan 1 indikator baru mencapai Cukup atau klasifikasi C. Rata-rata komponen indikator Baik.

Refleksi Setelah dilaksanakan tindakan penelitian siklus II melalui penerapan Active Knowledge Sharing yang lebih intensif, kemampuan guru SD Negeri 1 Wonokarto dalam pengelolaan kelas terjadi peningkatan Pada siklus II 
terjadi perubahan yang sangat baik jika dilihat dari siklus I yang sudah dilaksanakan tindakan penelitian melalui Active Knowledge Sharing kelompok, dan pada siklus II dilaksanakan tindakan penelitian melalui Active Knowledge Sharing yang lebih intensif.

Jika dilihat perbandingan peningkatan terjadi pada data berikut ini. Pada siklus I masih ada 2 orang guru $(25,0 \%)$ yang masuk kualifikasi Kurang. Nilai rata-rata kemampuan guru dalam pengelolaan kelas adalah 69,5 masuk kualifikasi Cukup.

Pada siklus II peneliti sudah melaksanakan tindakan penelitian melalui pelaksanaan Active Knowledge Sharing secara efektif. Kemampuan guru dalam pengelolaan kelas termasuk dalam kualifikasi Baik dengan rata-rata nilai 78,5. Ada 2 orang guru $(37,5 \%)$ yang masuk kualifikasi Amat Baik, ada 6 orang guru $(62,5 \%)$ masuk kualifikasi Baik, dan tidak ada guru yang masuk kualifikasi di bawah Baik.

Komponen kemampuan pengelolaan kelas guru SD Negeri 1 Wonokarto yang tercapai pada siklus II jika dibandingkan dengan kondisi awal dan siklus I terjadi peningkatan. Peningkatan, yaitu rata-rata kemampuan guru pada indikator komponen sudah masuk kualifikasi Baik.

Pada siklus II peneliti juga melaksanakan tindakan melalui penerapan Active Knowledge Sharing secara kelompok dengan bimbingan intensif. Kemampuan guru SD Negeri 1 Wonokarto dalam pengelolaan kelas pada siklus masuk dalam kualifikasi Baik dengan indikator komponen kemampuan yang Amat baik ada 4 indikator dan yang Baik ada 6 indikator dengan rata-rata B atau Baik,

Kemampuan guru SD Negeri 1 Wonokarto Tahun Pelajaran 2019/2020 dalam pengelolaan kelas pada siklus II menunjukkan peningkatan dan sudah berhasil memenuhi semua indikator kinerja penelitian.

Peningkatan kemampuan guru yang dicapai pada siklus II sudah memenuhi indikator kinerja dalam penelitian ini, maka peneliti memutuskan untuk menghentikan Penelitian Tindakan Sekolah ini. Jadi melalui penerapan Active Knowledge Sharing dapat meningkatkan kemampuan guru SD Negeri 1 Wonokarto dalam pengelolaan kelas Tahun Pelajaran 2019/2020. 


\section{b. Pembahasan}

Pada kondisi awal hasil observasi penulis sebagai kepala SD Negeri 1 Wonokarto menunjukkan bahwa guru tidak ada yang masuk predikat Baik atau Amat Baik, hasilnya hanya 2 orang guru (25\%) yang masuk predikat Cukup, 2 orang guru (25\%) yang masuk predikat Kurang dan masih ada 4 orang guru (50 \%) yang masuk predikat Sangat Kurang. Rata-rata bernilai 43,1 atau D kualifikasi Kurang.

Pada siklus I peneliti sudah melaksanakan tindakan penelitian melalui pelaksanaan Active Knowledge Sharing secara kelompok. Kemampuan guru dalam pengelolaan kelas dari hasil observasi siklus I bahwa guru yang hasilnya Baik ada 3 orang guru dengan nilai 70; 72,5; 75; setara dengan 37,5\%; yang masuk predikat Cukup, ada 5 orang guru dengan nilai dari 62, 5 sampai dengan 67,5; setara dengan 62,5 \%. Rata-rata nilai 69,8 kategori C atau kualifikasi Cukup. Rata-rata nilai 69,8 kategori C kualifikasi Cukup.

Pada siklus II peneliti sudah melaksanakan tindakan penelitian melalui pelaksanaan Active Knowledge Sharing secara efektif. Kemampuan guru dalam pengelolaan kelas dari hasil observasi siklus II bahwa guru yang hasilnya Amat Baik ada 2 orang guru dengan nilai 87,5 setara dengan $25 \%$ guru; yang masuk predikat Baik ada 6 orang guru dengan nilai dari 72, 5 sampai dengan 80 setara dengan $75 \%$ orang guru. Rata-rata nilai 78,5 kategori B kualifikasi Baik

Jadi melalui Active Knowledge Sharing dapat meningkatkan kemampuan guru SD Negeri 1 Wonokarto Tahun Pelajaran 2019/2020 dalam pengelolaan kelas. Dari kondisi awal nilai rata-rata kemampuan guru hanya 43,1 atau D kualifikasi Kurang, meningkat pada siklus I nilai rata-rata kemampuan guru menjadi 69,8 atau C kualifikasi Cukup, dan meningkat lagi pada siklus II nilai rata-rata kemampuan guru menjadi 78,5 atau B kualifikasi Baik. Maka indikator kinerja tercapai dan hipotesis terbukti kebenarannya.

Pada kondisi awal, belum dilaksanakan tindakan penelitian melalui Active Knowledge Sharing. Pada kondisi awal tidak ada guru yang kemampuannya masuk dalam kualifikasi Amat Baik, hanya 2 orang guru $(25,0 \%)$ yang masuk 
kualifikasi Cukup, ada 2 orang guru (25,0 \%) yang masuk kualifikasi Kurang.4 orang guru $(50,0 \%)$ yang masuk kualifikasi Sangat Kurang. Nilai rata-rata kemampuan guru dalam pengelolaan kelas pada kondisi awal adalah 43,1 masuk kualifikasi Kurang.

Pada siklus I peneliti sudah melaksanakan tindakan penelitian melalui pelaksanaan Active Knowledge Sharing secara kelompok. Kemampuan guru dalam pengelolaan kelas termasuk dalam kualifikasi Cukup dengan rata-rata nilai 69,8 . Ada 3 orang guru $(37,5 \%)$ yang masuk kualifikasi Baik, ada 5 orang guru $(62,5,0 \%)$ masuk kualifikasi Cukup. Nilai rata-rata kemampuan guru dalam pengelolaan kelas pada siklus I adalah 69,8 masuk kualifikasi Cukup.

Pada siklus II peneliti sudah melaksanakan tindakan penelitian melalui pelaksanaan Active Knowledge Sharing secara efektif. Kemampuan guru dalam pengelolaan kelas termasuk dalam kualifikasi Baik dengan rata-rata nilai 78,5. Ada 2 orang guru (37,5\%) yang masuk kualifikasi Amat Baik, ada 6 orang guru $(62,5 \%)$ masuk kualifikasi Baik, dan tidak ada guru yang masuk kualifikasi di bawah Baik.

Berdasarkan data di atas melalui Active Knowledge Sharing dapat meningkatkan kemampuan guru SD Negeri 1 Wonokarto Tahun Pelajaran 2019/2020 dalam pengelolaan kelas. Ukuran itu dilihat dari nilai rata-rata kemampuan guru dalam pengelolaan kelas pada kondisi awal adalah 43,1 masuk kualifikasi Kurang menjadi nilai rata-rata pada siklus I adalah 69,8 masuk kualifikasi Cukup dan berubah lagi meningkat menjadi kualifikasi Baik dengan rata-rata nilai 78,5 .

Pada kondisi awal ada 3 indikator komponen beroleh Kurang dan 7 indikator beroleh Sangat Kurang atau 10 indikator. Rata-rata E kualifikasi Sangat Kurang.

Pada siklus I ada 2 indikator komponen beroleh Baik, 4 indikator beroleh Cukup, 4 indikator Kurang Sedangkan peningkatan, yaitu rata-rata kemampuan guru sudah masuk kualifikasi Cukup dan jumlah guru yang masuk kualifikasi Baik ada 2 orang. Rata-rata C kualifikasi Cukup. 
Pada siklus II pelaksanaan tindakan dengan melalui penerapan Active Knowledge Sharing secara kelompok dengan bimbingan intensif, diperoleh kemampuan guru SD Negeri 1 Wonokarto dalam pengelolaan kelas pada siklus masuk dalam kualifikasi Baik dengan indikator komponen kemampuan yang Amat baik ada 4 indikator dan yang Baik ada 6 indikator, dengan rata-rata B atau Baik,

\section{Hasil Tindakan}

Pelaksanaan Penelitian Tindakan Sekolah melalui pelaksanaan Active Knowledge Sharing adalah sebagai berikut:

Melalui penerapan Active Knowledge Sharing dapat meningkatkan kemampuan guru SD Negeri 1 Wonokarto Tahun Pelajaran 2019/2020 dalam pengelolaan kelas. Dari kondisi awal nilai rata-rata kemampuan guru hanya 43,1 (kualifikasi Kurang), meningkat pada siklus I nilai rata-rata kemampuan guru menjadi 69,8 (kualifikasi Cukup), dan meningkat lagi pada siklus II nilai rata-rata kemampuan guru menjadi 78,5 (kualifikasi Baik). Terjadi pengingkatan dari kondisi awal sampai siklus II sebesar 78,5 - 43,1 = 35,4.

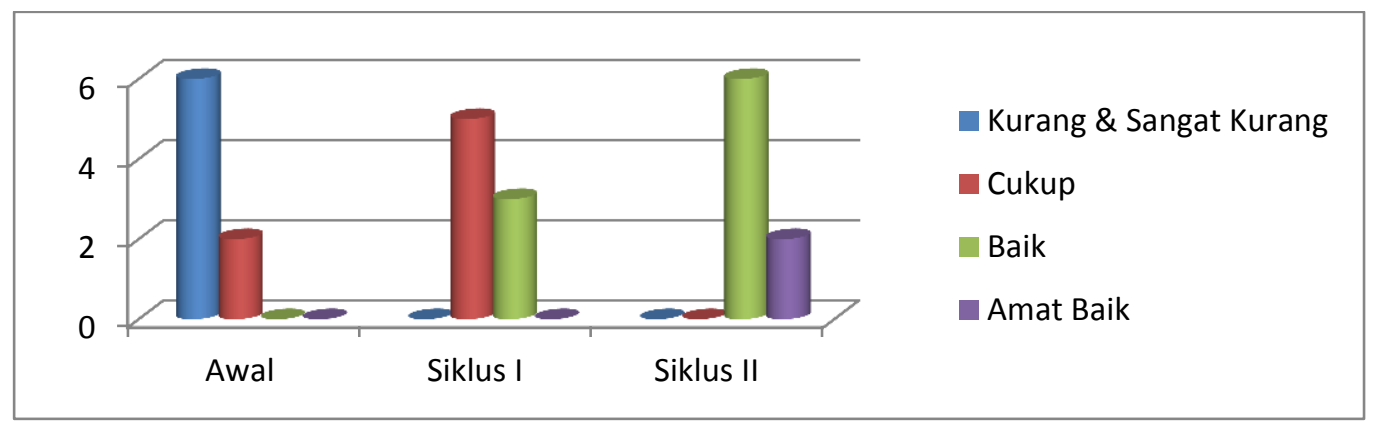

Gambar 1. Peningkatan Nilai Kondisi Awal, Siklus I, dan Siklus II Kemampuan Guru

Peningkatan juga ditunjukkan pada capaian indikator kinerja komponen kemampuan guru mengelola kelas. Pada kondisi awal 3 indikator komponen Kurang dan 7 indikator komponen Sangat Kurang, dengan rata-rata E atau Sangat Kurang. Pada siklus II meningkat menjadi 6 indikator komponen Baik dan 4 indikator komponen Sangat Baik, dengan rata-rata Baik. 


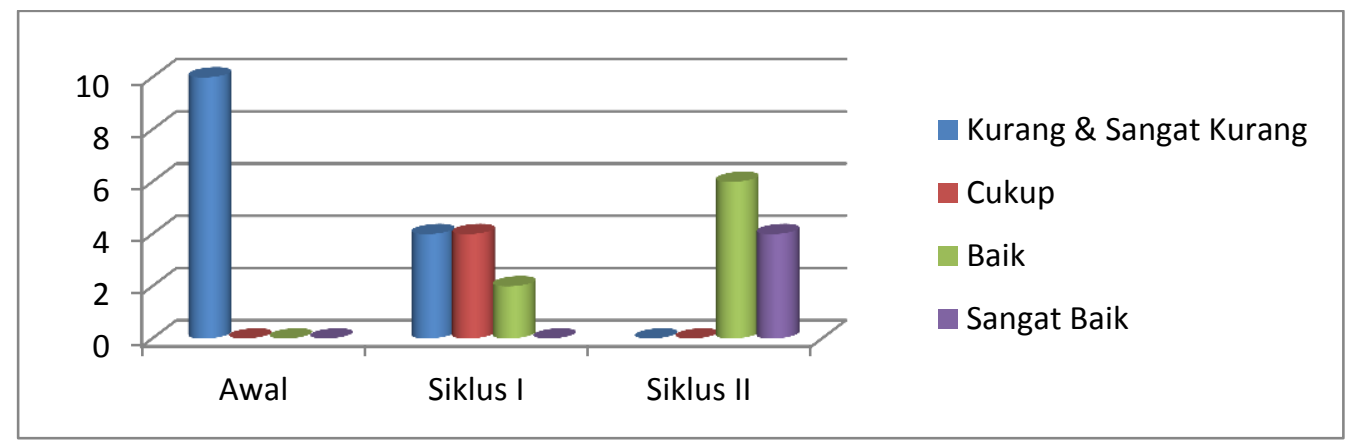

Gambar 2. Peningkatan Nilai Indikator Komponen Siklus II

Kemampuan Guru

Berdasarkan data di atas makan hipotesis yang berbunyi "Diduga melalui pelaksanaan active knowledge sharing dapat meningkatkan kemampuan guru dalam pengelolaan kelas diSD Negeri 1 Wonokarto Kecamatan Wonogiri Kabupaten Wonogiri Semester I Tahun Pelajaran 2019/2020.” terbukti kebenarannya.

\section{SIMPULAN}

Melalui penerapan Active Knowledge Sharing dapat meningkatkan kemampuan guru SD Negeri 1 Wonokarto Tahun Pelajaran 2019/2020 dalam pengelolaan kelas. Dari kondisi awal nilai rata-rata kemampuan guru hanya 43,1 (kualifikasi Kurang), meningkat pada siklus I nilai rata-rata kemampuan guru menjadi 69,8 (kualifikasi Cukup), dan meningkat lagi pada siklus II nilai rata-rata kemampuan guru menjadi 78,5 (kualifikasi Baik). Terjadi pengingkatan dari kondisi awal sampai siklus II sebesar 78,5 - 43,1 = 35,4.

Peningkatan juga ditunjukkan pada capaian indikator kinerja komponen kemampuan guru mengelola kelas. Pada kondisi awal 3 indikator komponen Kurang dan 7 indikator komponen Sangat Kurang, dengan rata-rata E atau Sangat Kurang. Pada siklus II meningkat menjadi 6 indikator komponen Baik dan 4 indikator komponen Sangat Baik, dengan rata-rata Baik.

Kesimpulan yang dapat ditarik adalah melalui penerapan active knowledge sharing dapat meningkatkan kemampuan guru SD Negeri 1 Wonokarto Tahun Pelajaran 2019/2020 dalam pengelolaan kelas.

Implikasi adalah simpulan yang disajikan sebagai pelengkap dari simpulan sebagai jawaban hipotesis yang tersaji. Adapun implikasinya sebagai berikut: 1). 
Dua orang guru memperoleh klasifikasi A atau Amat Baik dan enam guru memperoleh klasifikasi B atau Baik yang berarti delapan guru sudah mampu mengelola kelas dengan Baik. Oleh karena itu tindakan sekolah dihentikan karena sudah mencapai indikator kinerja Baik; 2) Kemampuan pengelolaan kelas per indikator komponen diperoleh hasil empat indikator komponen klasifikasi A atau Amat Baik dan enam indikator komponen klasifikasi B atau Baik.. Artinya ke-10 indikator komponen tercapai.

Dari penelitian ini dapat disarankan hal-hal sebagai berikut: 1) Kepada guru hendaknya menciptakan kegiatan pembelajaran yang kondusif dan menyenangkan, serta mampu mengelola kelas dengan baik; 2) Guru-guru yang sudah berpengalaman dapat dijadikan supervisor bagi guru lain yang dipandang kurang mampu, untuk meningkatkan kualitas pembelajaran di kelas; 3) Untuk kepala sekolah sejenis dapat menggunakan penelitian ini sebagai rujukan kinerjanya.

\section{DAFTAR PUSTAKA}

Ade Rukmana dan Asep Suryana. 2006. Pengelolaan Kelas. Bandung: UPI Press

Adhayati, Suid,Tursinawati. 2016. Kemampuan Guru Dalam Mengelola Kelas Untuk Siswa Yang Berkebutuhan Khusus Di SDN 16 Banda Aceh. Jurnal Ilmiah Pendidikan Guru Sekolah Dasar FKIP Unsyiah Volume 1 Nomor 2, 1-10 Oktober 2016

Dendy Sugono. 2010. Kamus Bahasa Indonesia. Jakarta: Pusat Bahasa Departemen Pendidikan Nasional

Dewi, 2012. Dasar - Dasar Evaluasi Pendidikan. Jakarta : Bumi Aksara

Iskandar. 2009. Psikologi Pendidikan: Sebuah Orientasi Baru. Jakarta: Gaung Persada

Mantja, W. 2007. Profesionalisasi Tenaga Kependidikan: Manajemen Pendidikan dan Supervisi Pengajaran. Malang: Elang Mas

Nafi'a, 2012, Pengaruh Penggunaan Model Active Knowledge Sharing dalam Pembelajaran. Yogyakarta: Pustaka Insan Madani 
Rina Apriliyana dan Benedictus Kusmanto. 2016. Penerapan Strategi Active Knowledge Sharing Untuk Meningkatkan Minat dan Prestasi Belajar Matematika Siswa Kelas X-A SMA Piri 1 Yogyakarta. UNION: Jurnal Pendidikan Matematika Vol 4 No 1, Maret 2016

Silberman, Mel. 2009. Active Learning 101 Strategi Pembelajaran Aktif. Diterjemahkan oleh Sarjuli dkk. Yogyakarta: Pustaka Insan Madani dan YAPPENDIS

Siwi, D. A. 2018. Hubungan Penggunaan Media Pembelajaran Grafis dengan Hasil Belajar Matematika Siswa Kelas IV. Jurnal Dikdas Bantara, 1(2).

Uzer, Usman. 2005. Menjadi Guru Profesional, Bandung: PT Remaja Rosda Karya.

Wijaya, H. ES dan Tabrani Rusyan. 2012. Profesionalisme Tenaga Kependidikan. Bandung: Nine KaryaJaya

Zaini, Hisyam, 2008, Strategi Pembelajaran Aktif. Yogyakarta : Pustaka Pelajar 